О. О. Бондаренко, Н. С. Петрук, І. С. Шпонька

ДЗ “Дніпропетровська медична академія МОЗ України”, м. Дніпро

\title{
ДОСВІД ВПРОВАДЖЕННЯ МЕТОДУ НАВЧАННЯ НА КАФЕДРІ ПАТОЛОГІЧНОЇ АНАТОМІЇ, ОСНОВАНОГО НА ПРИНЦИПІ РОЗБОРУ КЛІНІЧНИХ ВИПАДКІВ (САSE-ВASED LEARNING). ЧАСТИНА 2: АНАЛІЗ РЕЗУЛЬТАТІВ ВПРОВАДЖЕННЯ
}

\author{
O. O. Bondarenko, N. S. Petruk, I. S. Shponka \\ Dnipropetrovsk Medical Academy of Ministry of Health of Ukraine, Dnipro

\section{THE EXPERIENCE OF CLINICAL CASE STUDY PRINCIPLE BASED METHOD (CASE-BASED LEARNING) IMPLEMENTATION AT PATHOLOGIC ANATOMY DEPARTMENT. PART 2: IMPLEMENTATION ANALYSIS}

\begin{abstract}
Мета роботи. Стаття присвячена аналізу результатів апробації методу викладання, основаного на принципі розбору клінічних випадків, що проводилося на кафедрі патологічної анатомії ДЗ “ДМА МОЗ України” протягом 2016-2017 академічного року. Дану методику оцінювали з погляду ефективності підготовки студентів до державного іспиту “Крок-1” та за допомогою опитування студентів щодо задоволеності новим методом викладання.

Основна частина. Досліджуваний метод навчання був впроваджений на практичних заняттях поряд із збереженим графіком лекцій серед груп англомовних студентів медичного факультету третього курсу у 2016-2017н. р. У цілому, в апробації методу взяли участь 129 студентів. Показано, що переважна більшість студентів (81 \%), що взяли участь в опитуванні, позитивно схвалювали запропонований метод навчання, також відзначався приріст відсотка успішного складання тестового проміжного контролю на зимовій сесії з курсу “Загальна патоморфологія” при порівнянні з минулорічним результатом.

Висновок. Робота з отриманим в якості завдання персональним клінічним випадком наближає студента до сценаріїв із майбутньої практичної діяльності та, як результат, стимулює і мотивує його отримувати якісні професійні знання.
\end{abstract}

Ключові слова: медична освіта; патоморфологія; case-based learning; інтерактивне навчання.

The aim of the work - to analyze the results of clinical case study principle based method (case-based learning) implementation carried out at the Pathologic Anatomy Department of Dnipropetrovsk Medical Academy of Ministry of Health of Ukraine during 2016-2017 academic year. This technique was evaluated in terms of efficacy of student preparation for the state exam "Krok-1" and by questioning students about satisfaction with the new method of teaching.

The main body. Investigated teaching method was introduced at workshops along with scheduled lectures saved among most thirdyear English-speaking medical students. In general, the testing method was attended by 129 students. It is shown that the vast majority of respondents (81 \%) who participated in the survey positively approved the proposed teaching method. It was demonstrated the growth of the interim control test passing rate at the winter session of the course "General Pathomorphology" comparing to previous years result.

Conclusion. Personalized working with clinical cases brings the students to the scenarios of future practice and as a result, encourages and motivates them to get high-quality expertise.

Key words: medical teaching; pathmorphology; case-based learning; interactive teaching.

Вступ. Методологія традиційної системи медичної освіти включає в себе проведення лекцій, практичних занять та виконання студентами самостійної роботи [1]. Нерідко у центрі педагогічного процесу стоїть викладач, що призводить до мінімальної активності та залучення студентів до навчального процесу й критичного аналізу проблемних питань.

(c) О. О. Бондаренко, Н. С. Петрук, І. С. Шпонька
Проте майбутні фахівці у галузі охорони здоров’я повинні розвивати аналітичні та діагностичні навички мислення, бути більш автономними i, в той же час, підтримувати високий рівень комунікативних здібностей, а не просто накопичувати велику кількість профільного медичного матеріалу [2].

Навчання, основане на принципі розбору клінічних випадків, є широко розповсюдженим, застосо- 
вується у різних галузях освіти, визначається змістом обраного випадку (case) та використовується для навчання у багатьох університетах світу [3]. Як було зазначено в першій частині цієї роботи [4], і як про це свідчать інші дослідження [3, 5-8], casebased learning метод є успішною альтернативою традиційній методиці викладання патологічної анатомії, оскільки покращує логічні навички студентів, стимулює клінічне мислення, сприяє розвитку автономності, розвиває комунікативні навички, приводить до кращого збереження знань та стимулює мотивацію студента до навчання.

Мета роботи. Стаття присвячена аналізу результатів апробації методу викладання, основаного на принципі розбору клінічних випадків, що проводилося на кафедрі патологічної анатомії ДЗ “ДМА MO3 України” протягом 2016-2017 академічного року. Дану методику оцінювали з погляду ефективності підготовки студентів до державного іспиту “Крок-1”. Досліджуваний метод викладання був упроваджений на практичних заняттях поряд із збереженим графіком лекцій серед груп англомовних студентів медичного факультету третього курсу у 2016-2017 н. р. У цілому, в апробації методу взяли участь 129 студентів.

Основна частина. У першій частині цієї роботи ми детально описували принцип запропонованого методу та алгоритм методологічної підготовки матеріалів до занять, що мало на меті створення найбільш релевантних клінічних завдань. У даній роботі викладені й проаналізовані соціологічні та статистичні результати впровадження.

Апробація проведення практичних занять з патоморфології за описаною методикою продемонструвала декілька позитивних тенденцій. По-перше, слід зазначити ефективне застосування дистанційних методів навчання на етапі підготовки студента до наступного заняття. Завдяки використанню інформаційних технологій стало можливим оперувати більш якісною та сучасною інформацією, що є доступною для кожного інтернет-користувача. Більше того, навіть на етапі підготовки студента до наступного практичного заняття був можливий моніторинг його активності та заохочення до ефективної роботи.

3 метою отримання зворотного зв'язку від студентів нами було створено опитування за допомогою доступних інструментів у соціальній мережі Facebook. Було досліджене твердження: “Я задоволений існуючим методом викладання патологічної анатомії” з варіантами відповідей “Повністю згоден”, “Згоден”, “Частково згоден”, “Не згоден”, “Повністю не зго-

ден”. Із 129 студентів першого міжнародного факультету на третьому академічному році навчання в опитуванні взяли участь 52 респонденти (40 \%). 3 них 50 \% (26 респондентів) відповіли, що вони “Повністю задоволені” впровадженою методикою викладення, 31 \% студентів також у цілому схвалювали апробований принцип навчання, обравши відповідь “Задоволений” (рис. 1). Решта студентів (19 \%) мала певні сумніви щодо зацікавленості описаним принципом навчання.

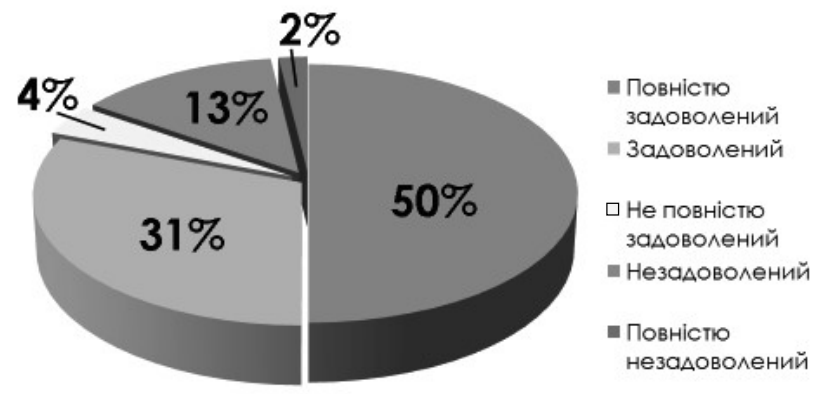

Рис. 1. Результати опитування студентів 3 курсу 1-го міжнародного факультету ДЗ “ДМА МОЗУ” щодо задоволеності ведення практичних занять з патоморфології запроваджуваним методом. Результати отримані 14.03.2017 p.

Окрім того, був порівняний відсоток успішного складання тестового проміжного контролю на зимовій сесії з курсу “Загальна патоморфологія” серед англомовних студентів 2015-2016 і 20162017 навчальних років (рис. 2). Був відмічений приріст частки успішно складених тестових завдань на 5,65 \%. Звичайно, що самі по собі, без аналізу впливу додаткових факторів, ці дані не можуть безпосередньо свідчити про ефективність даного методу навчання. Однак певна позитивна тенденція спонукає до його подальшого застосування і майбутній моніторинг успішності студентів, напевне,

2015-2016

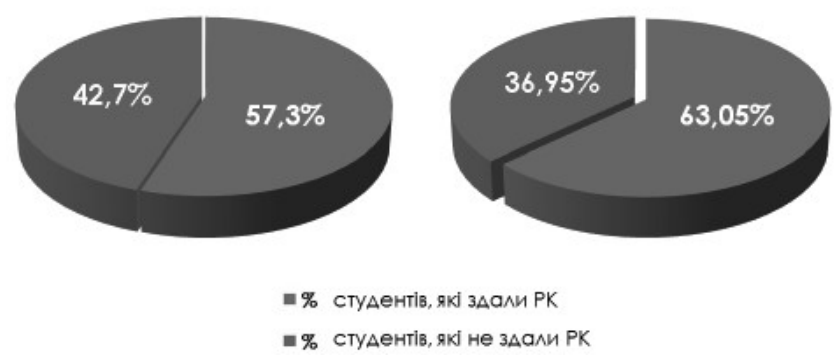

Рис. 2. Порівняння результатів складання тестового проміжного контролю (зимова сесія) з курсу

“Загальна патоморфологія” серед англомовних студентів 2015-2016 (класична схема навчання) і 2016-2017

(апробація case-based learning) років навчання. 
проллє більше світла в питанні ефективності апробованої методики.

Висновки. Таким чином, отримані дані соціологічного моніторингу та порівняльний аналіз результатів складання проміжних тестових іспитів 3 циклу “Загальна патологічна анатомія” демонструють переваги застосування описаної методики, базованої на принципі розбору клінічних випадків, як

\section{Список літератури}

1. Huggett K. N. Introduction to Medical Teaching / K. N. Huggett, W. B. Jeffries. - [2nd edition]. - NY : Springer, 2014. - 286 p.

2. Гаврилюк А. О. Роль патологічної анатомії в системі медичної освіти та формуванні професійних навичок майбутніх лікарів / А. О. Гаврилюк, Г. М. Галунко, Т. М. Король // Проблеми та перспективи вищої медичної школи у розробці та реалізації національної стратегії побудови нової системи охорони здоров'я в Україні на період 2015-2025 рр. : зб. матеріалів навч.-метод. конф., 25 бер. 2015 р. - Вінниця, 2015. - С. 26-27.

3. Case based learning: a method for better understanding of biochemistry in medical students / S. P. Nair, T. Shah, S. Seth [et al.] // J. Clin. and Diagno. Res. - 2013. - Vol. 7, № 8. - Р. 1576-1578.

4. Бондаренко О. О. Досвід впровадження методу навчання на кафедрі патологічної анатомії, основаного на принципі розбору клінічних випадків. Частина 1: опис

\section{References}

1. Jeffries, W.B., \& Huggett, K. (Eds.). (2014). An introduction to medical teaching. Springer Science \& Business Media.

2. Havryliuk, A.O., Halunko, H.M., \& Korol, T.M. (2015). Rol patolohichnoi anatomii v systemi medychnoi osvity ta formuvanni profesiinykh navychok maibutnikh likariv [The role of pathological anatomy in future doctors' medical education and skills formation]. Navch.-metod. conf "Problemy ta perspektyvy vyshchoi medychno shkoly $u$ rozrobtsi ta realizatsii Natsionalnoi stratehii pobudovy novoi systemy okhorony zdorovia v Ukraini na period 2015-2025 rr. Educational and methodological conference "Problems and Prospects of Higher Medical Education in Developing and Implementing a National Strategy of New Health Care System Development in Ukraine for the Period of 2015-2025 years”. (pp. 26-27). Vinnytsia [in Ukrainian].

3. Nair, S.P., Shah, T., Seth, S., Pandit, N., \& Shah, G.V. (2013). Case based learning: a method for better understanding of biochemistry in medical students. Journal of Clinical and Diagnostic Research: JCDR, 7(8), 1576-1578. у вигляді більшого заохочення студентів у навчанні, так і у покращенні результатів складання іспитів. Робота з отриманим в якості завдання персональним клінічним випадком наближає студента до сценаріїв із майбутньої практичної діяльності та, як результат, стимулює і мотивує його отримувати якісні професійні знання.

методу / О. О. Бондаренко, Н. С. Петрук, І. С. Шпонька // Медична освіта. - 2017. - № 2. - С. 102-106.

5. Buch A. C. Interactive teaching: Understanding perspectives of II MBBS students in pathology / A. C. Buch, S. S. Chandanwale, S. A. Bamnikar // Med. J. D. Y. Patil. Univ. - 2014. - Vol. 7. - P. 693-695.

6. Marshall R. Teaching and learning pathology: a critical review of the English literature / R. Marshall, N. Cartwright, K. Mattick // Med Educ. - 2004. - Vol. 38, № 3. P. 302-313.

7. Stahl S. M. Best practices in medical teaching / S. M. Stahl, R. L. Davis. - NY : Cambridge University Press, 2011. - 178 p.

8. Undergraduate medical students' feedback and perceptions on teaching learning methodology in Pathology at Government Medical College / S. S. S. Quadri, S. Shyamala, S. Mahesh, B. Bheeshma // IAIM. - 2016. - Vol. 3, № 7. - P. 28-35.

4. Bondarenko, O.O., Petruk, N.S., \& Shponka, I.S. (2017). Dosvid vprovadzennia metodu navchannia na kafedri patolohichnoi anatomii, osnovanoho na pryntsypi rozboru klinichnykh vypadkiv. Chastyna 1: opys metodu [Experience of implementation of teaching method at the Department of Pathological Anatomy, based on the principle of clinical cases selection. Part 1: method description]. Medychna osvita - Medical Education, 2, 102 [in Ukrainian].

5. Buch, A.C., Chandanwale, S.S., \& Bamnikar, S.A. (2014). Interactive teaching: Understanding perspectives of II MBBS students in Pathology. Medical Journal of Dr. DY Patil University, 7(6), 693.

6. Marshall, R., Cartwright, N., \& Mattick, K. (2004). Teaching and learning pathology: a critical review of the English literature. Medical Education, 38(3), 302-313.

7. Stahl, S. M., \& Davis, R. L. (2011). Best practices in medical teaching. Cambridge University Press.

8. Quadri, S.S.S., Shyamala, S., Mahesh, S., \& Bheeshma, B. (2016). Undergraduate medical students’ feedback and perceptions on teaching learning methodology in Pathology at Government Medical College. IAIM, 3(7), 28-35. 